\title{
10. ANALYSIS AND INTERPRETATION OF THE BOREHOLE TELEVIEWER LOG: INFORMATION ON THE STATE OF STRESS AND THE LITHOSTRATIGRAPHY AT HOLE 504B ${ }^{1}$
}

\author{
Roger H. Morin, ${ }^{2}$ Roger N. Anderson, ${ }^{3}$ and Colleen A. Barton ${ }^{4}$
}

\begin{abstract}
Hole 504B in the eastern equatorial Pacific has been the focus of several scientific expeditions during the past few years, where a series of re-entry, drilling, and coring operations has yielded important data regarding the structure of the upper kilometer of the oceanic lithosphere. As part of the extensive downhole experiments program planned for ODP Leg 111 at this site, a borehole televiewer (BHTV) log was obtained across a 355-m vertical section of crustal basement, extending upward from 1531 to $1176 \mathrm{~m}$ below the seafloor. The BHTV record was analyzed in terms of both acoustic amplitude and traveltime in order to accurately identify zones of structural failure in the surrounding basement rock. A subsequent examination of breakout frequency vs. azimuth helped identify the orientation of in-situ horizontal principal stresses according to the well-substantiated hypothesis that breakouts occur coincident with the direction of minimum principal stress $\left(S_{h}\right)$ where compressive forces are at their greatest. This $S_{h}$ orientation is found to be $\mathrm{N} 122.5^{\circ} \mathrm{E}$, a direction that agrees closely with the results of a previous BHTV study of breakouts in the upper section of this same borehole and also with stress orientation estimates inferred from regional intraplate earthquakes. The distribution of breakout frequency vs. azimuth shows the data to be bimodal and orthogonal to a degree that is statistically significant. The $S_{h}$ direction is inferred from the primary mode. The orthogonal pattern indicates that a considerable number of wellbore enlargements were detected coincident with the direction of maximum principal stress $\left(S_{H}\right)$. These are interpreted as extensional fractures produced by localized tensional stresses parallel with the $S_{H}$ orientation. Consideration of various hydraulic fracturing schemes and attendant analyses indicates that these fractures are likely to be induced when the ratio of effective horizontal principal stresses $\left(S_{H} / S_{h}\right)$ is very large in a cylindrical wellbore or is somewhat smaller in a hole exhibiting a slight degree of ellipticity. This hypothesis is supported by the solutions to source mechanism studies associated with local earthquakes that indicate a strike-slip sense of faulting and a relative order of stress magnitude where $\bar{S}_{H} \gg \bar{S}_{h}$. The bimodal, orthogonal distribution of wellbore enlargements also results in a slight correction to the method used for estimating the principal stress orientation, one based upon the population modes rather than the mean.

Inspection of three-dimensional images generated from the BHTV record in the lower portion of the borehole reveals the surprising appearance of pillow lavas at a depth previously assumed to be composed of sheeted dikes. When the ophiolite analogy is applied to contemporary oceanic crust, the transitional unit between the upper pillow lavas and minor flows and the variably metamorphosed diabase dikes below seems to be a complex, gradual, and gradational interlayering of lithologies that extends over a thicker vertical interval than previously thought.
\end{abstract}

\section{INTRODUCTION}

Hole 504B is located in 5.9-m.y.-old crust about $200 \mathrm{~km}$ south of the Costa Rica Rift (Fig. 1). This site is associated with a long history of successful scientific ventures, starting in 1979 when it was cored to a depth of $836 \mathrm{~m}$ below seafloor (mbsf) during Deep Sea Drilling Program (DSDP) Legs 69 and 70 (Cann, Langseth, et al., 1983). Hole 504B was revisited during DSDP Legs 83 (Anderson, Honnorez, et al., 1985) and 92 (Leinen, Rea, et al., 1986), and the hole was deepened by 212.3 m during Ocean Drilling Program (ODP) Leg 111 to a total depth of 1562.3 mbsf. As part of the extensive geophysical logging and downhole experiments program planned during Leg 111 , a borehole televiewer (BHTV) log was obtained across a 355-m vertical section of basement rock, extending upward from 1531 to $1176 \mathrm{mbsf}$. The top $100 \mathrm{~m}$ of this record overlaps the televiewer log previously obtained during Leg 83 in 1981 (Newmark et al., 1985).

\footnotetext{
${ }^{1}$ Becker, K., Sakai, H., et al., 1989. Proc. ODP, Sci. Results, 111: College Station, TX (Ocean Drilling Program).

2 U.S. Geological Survey, P.O. Box 25046, Denver Federal Center, Denver, CO 80225 .

${ }^{3}$ Lamont-Doherty Geological Observatory of Columbia University, Palisades, NY 10964.

${ }^{4}$ Department of Geophysics, Stanford University, Stanford, CA 94305.
}

A geothermal televiewer was provided by the U.S. Geological Survey in anticipation of relatively high downhole temperatures to be encountered at this site (see Gable et al., this volume). The BHTV is an ultrasonic logging instrument that produces a magnetically oriented image of the borehole wall; its principle of operation is described in detail by Zemanek et al. (1969). The BHTV record can be processed in terms of acoustic reflectivity to produce a photographic image of the borehole wall. This most recent version of the televiewer log from Hole 504B is presented in the Leg 111 Initial Reports (Becker, Sakai, et al., 1988). The acoustic waveforms generated by the BHTV can also be processed in the time domain to produce a horizontal cross-sectional image, or a $360^{\circ}$ caliper approximation, of the borehole (Georgi, 1985; Lysne, 1986). The BHTV log obtained during ODP Leg 111 has been analyzed from both perspectives (amplitude and traveltime). The results are examined within a tectonic context to gain information concerning the state of stress and the lithostratigraphic structure of the oceanic crust at Hole 504B.

\section{STATE OF STRESS}

\section{Location and Distribution of Breakouts}

The use of stress-induced wellbore breakouts as indicators of in-situ stress orientation is well documented (Bell and Gough, 1979; Gough and Bell, 1982; Zoback et al., 1985; Paillet and 


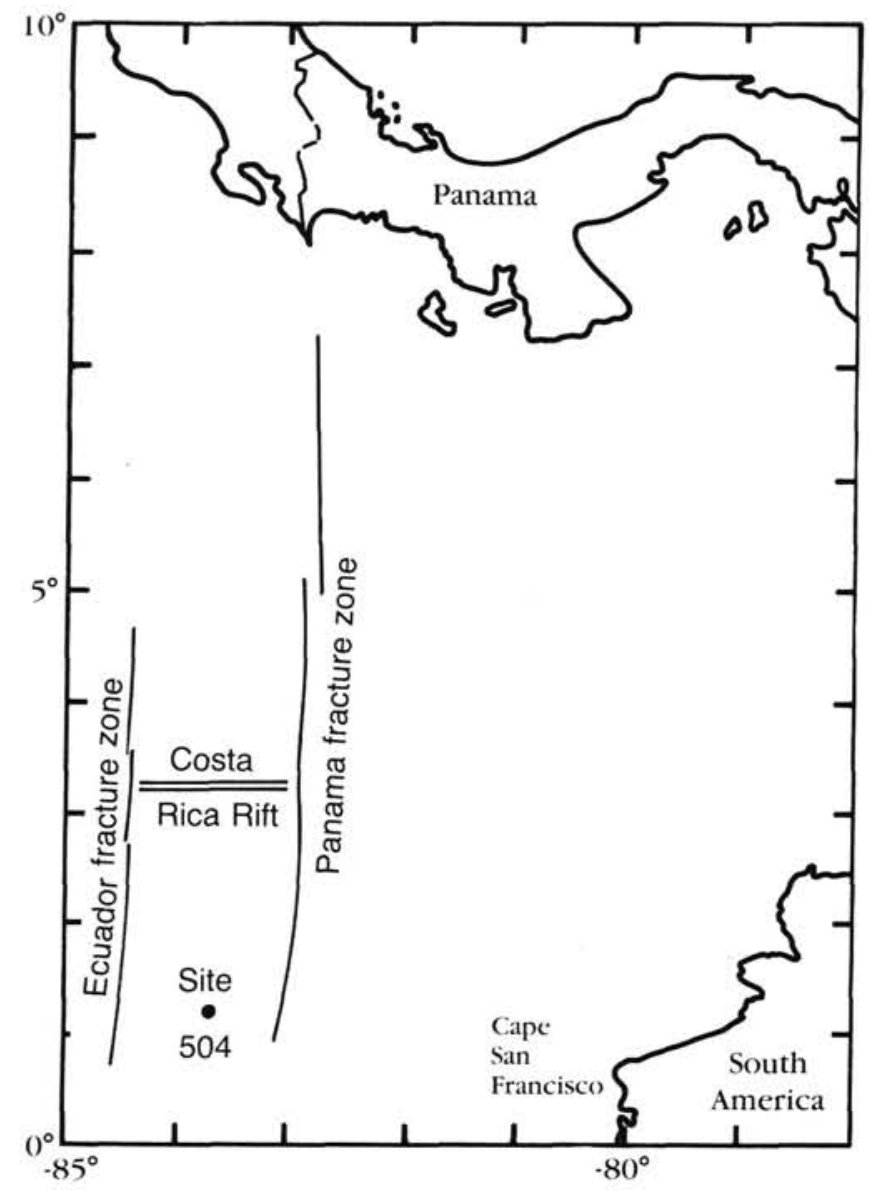

Figure 1. Location of Hole 504B in the eastern equatorial Pacific.

Kim, 1987; Plumb and Cox, 1987). Spalling resulting from conjugate shear fractures around a borehole can be related to the directions of the horizontal principal stresses in the upper crust. The breakouts accumulate at the azimuth of the least horizontal principal stress $\left(S_{h}\right)$ where the compressive stress in the rock is the greatest. Several studies have shown that stress information derived from breakout data correlates closely with the in-situ stress orientation determined by other independent means (Hickman et al., 1985; Plumb and Hickman, 1985; Teufel, 1985).

For a vertical hole of circular cross section, the distributions of stress components in the surrounding rock are determined to be as follows (Timoshenko and Goodier, 1970; Jaeger and Cook, 1976):

$$
\begin{gathered}
\sigma_{r}=0.5\left(\bar{S}_{H}+\bar{S}_{h}\right)\left(1-R^{2} / r^{2}\right)-0.5\left(\bar{S}_{H}-\bar{S}_{h}\right) \\
\left(1-4 R^{2} / r^{2}+3 R^{4} / r^{4}\right) \cos 2 \theta+\Delta P R^{2} / r^{2} \\
\sigma_{\theta}=0.5\left(\bar{S}_{H}+\bar{S}_{h}\right)\left(1+R^{2} / r^{2}\right) \\
+0.5\left(\bar{S}_{H}-\bar{S}_{h}\right)\left(1+3 R^{4} / r^{4}\right) \cos 2 \theta \\
\quad-\Delta P R^{2} / r^{2} \\
\tau_{r \theta}=-0.5\left(\bar{S}_{H}+\bar{S}_{h}\right)\left(1+2 R^{2} / r^{2}-3 R^{4} / r^{4}\right) \sin 2 \theta,
\end{gathered}
$$

where $\sigma_{r}$ is the radial stress, $\sigma_{\theta}$ is the circumferential stress, $\tau_{r \theta}$ is the tangential stress, $R$ is the radius of the borehole, $r$ is the distance from the center, and $\theta$ is the azimuth measured from the direction of effective minimum principal stress, $\bar{S}_{h}$ (Fig. $2 \mathrm{~A}$ ). $\bar{S}_{H}$ is the effective maximum principal stress, and $\Delta P$ is the hydraulic head difference between the borehole fluid and the pore pres-

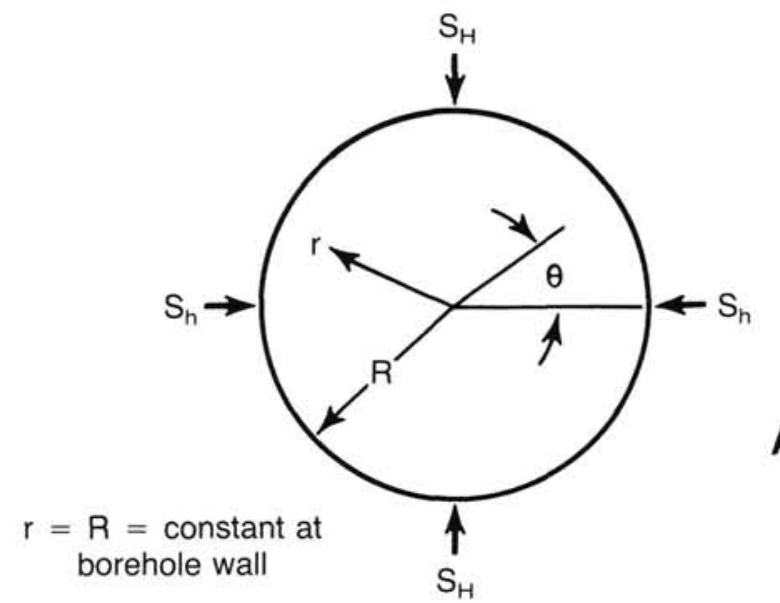

A

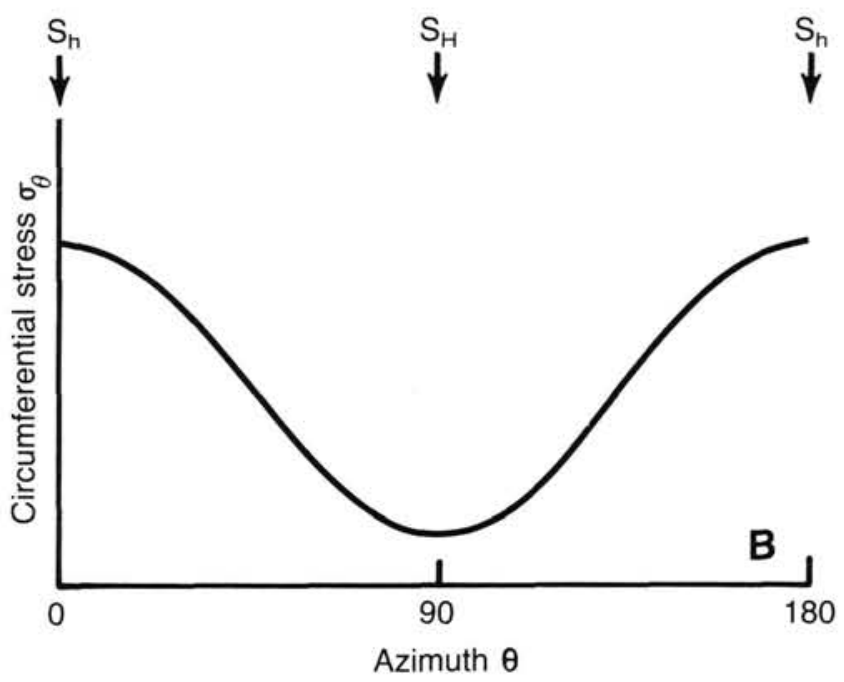

Figure 2. Schematic diagrams of (A) circular borehole cross section with (B) corresponding distribution of circumferential stress. Terms are defined in the text.

sure, $P_{p}$, in the formation. For the purposes of this study, it is assumed that $\bar{S}_{i}=S_{i}-P_{p}$, where $S_{i}$ is the total principal stress.

At the borehole wall $(r=R)$, only the circumferential stress is nonzero at hydrostatic conditions $(\Delta P=0)$ and, for conditions in which effective horizontal principal stresses are unequal, is a maximum at $\theta=0^{\circ}$ and a minimum at $\theta=90^{\circ}$ (Fig. 2B).

$$
\begin{aligned}
& \text { At } \theta=0^{\circ}, \sigma_{\theta}=3 \bar{S}_{H}-\bar{S}_{h} \\
& \text { At } \theta=90^{\circ}, \sigma_{\theta}=3 \bar{S}_{h}-\bar{S}_{H} .
\end{aligned}
$$

Borehole breakouts were initially identified in the continuous sequence of photographic images generated by the BHTV. These were indicated in the record by coincident broad and dark bands (no acoustic reflectivity) approximately $180^{\circ}$ apart. Further processing and analysis of the acoustic traveltime data yielded cross-sectional views of the borehole, and systematic stacking of these intervals yielded three-dimensional, cylindrical illustrations. Details of this processing technique are described by Barton et al. (1988). A series of these images associated with three different stress conditions is presented in Figure 3. This composite depicts moderate breakouts at 1177 mbsf (Fig. 3A), large 


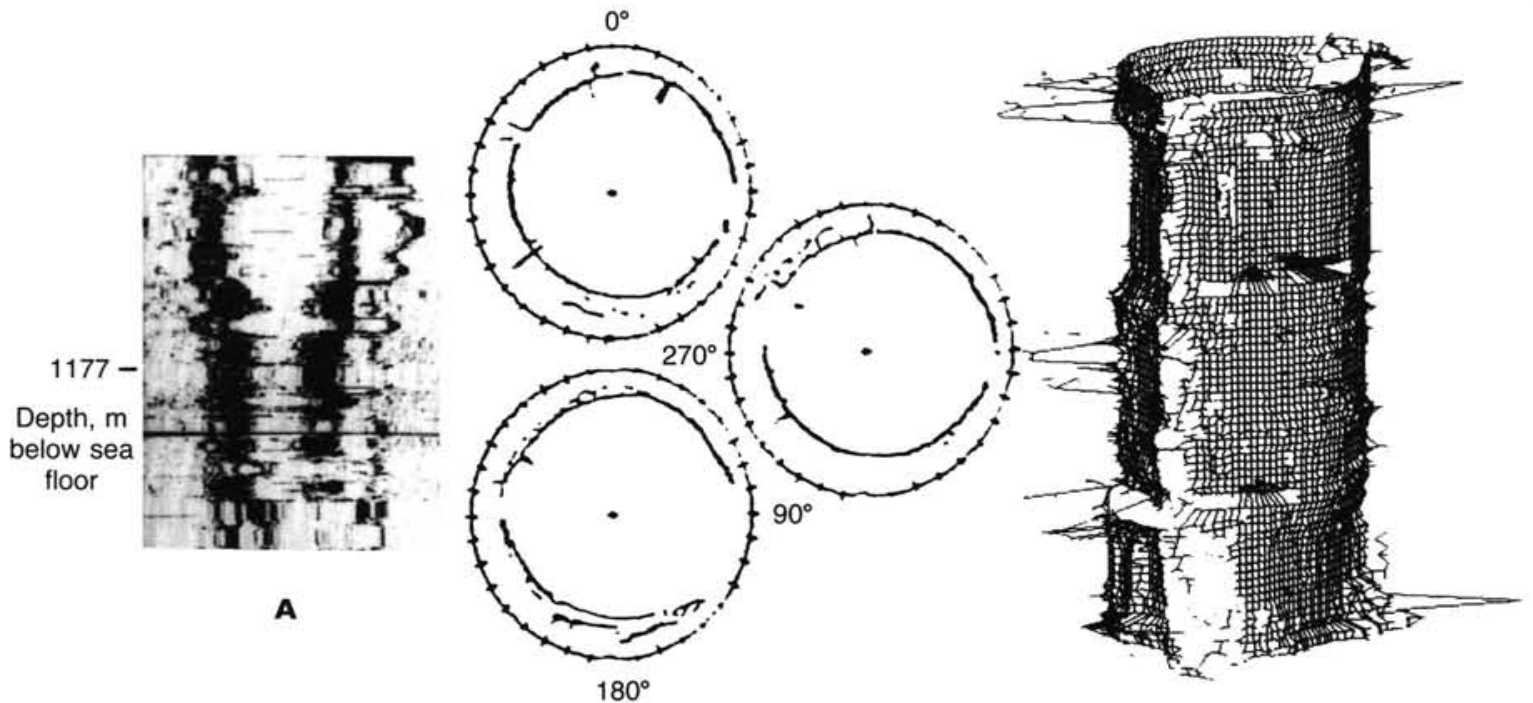

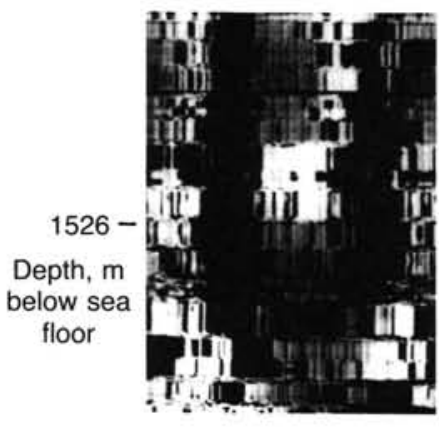

B
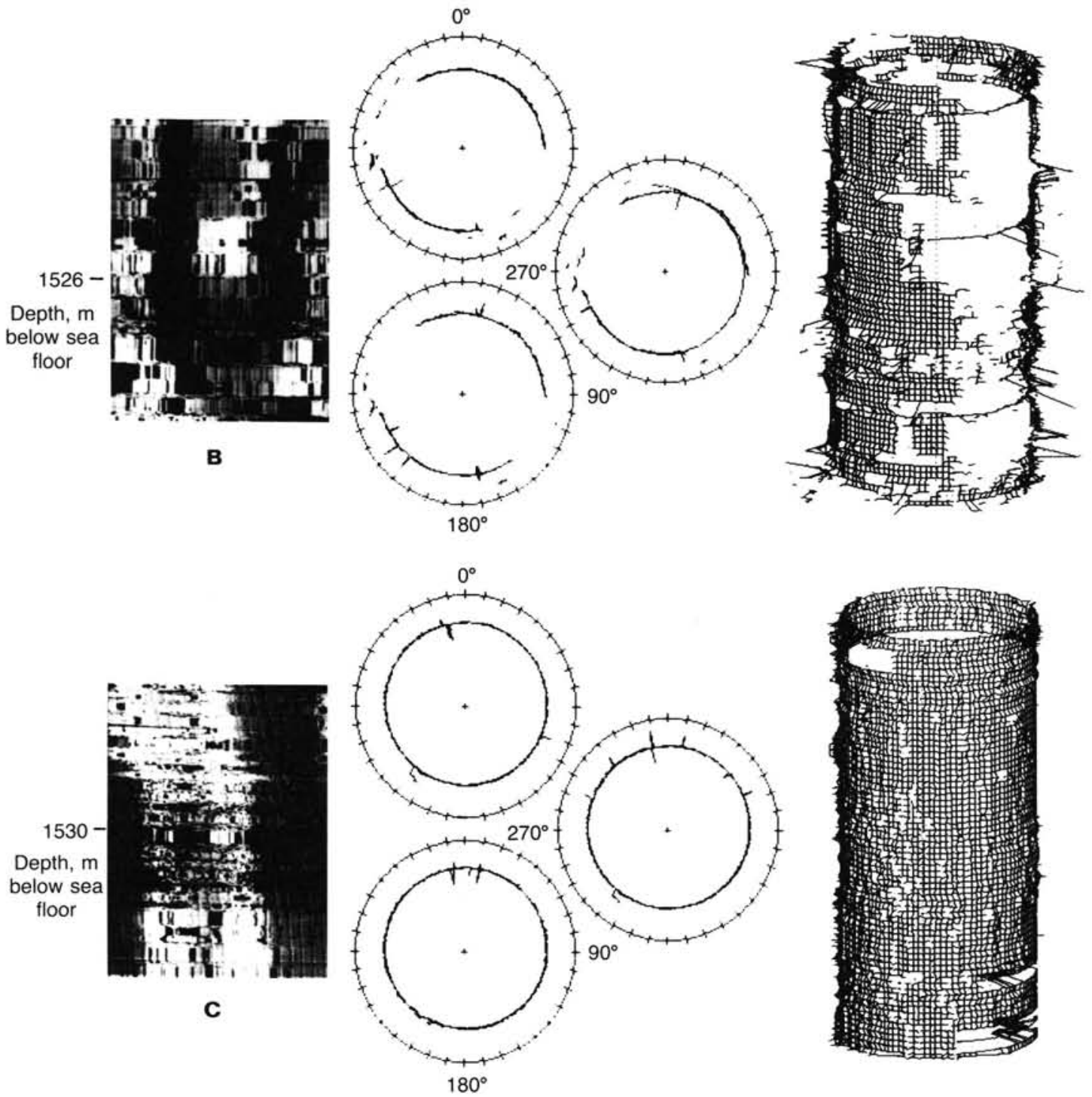

Figure 3. Composite image produced from the BHTV record consisting of a photographic copy, a typical polar cross section, and a series of cross sections superimposed to produce a three-dimensional projection. A. Moderate breakouts at $1177 \mathrm{mbsf}$. B. Large breakouts at 1526 mbsf. C. Competent, "gun barrel" structure directly below the large breakouts in Figure 3B. 
breakouts at 1526 mbsf (Fig. 3B), and competent rock with no evidence of spalling directly below the large breakouts of Figure 3B (Fig. 3C).

The substantial breakouts shown in Figure 3B are clearly identified in all three images, regardless of the data-processing method. The moderate breakouts of Figure $3 \mathrm{~A}$ are well defined in the cross-sectional and three-dimensional views, but are less evident from the photographic image based on acoustic reflectivity. Methodical examination of the borehole cross sections seems to be a more sensitive and reliable technique for identifying rock deformation and fracture failure than the more conventional method of searching for markedly dark bands on the photographic copy. A competent rock structure free of any spalling, possibly as a result of localized stress relaxation caused by the large breakouts directly above, is shown in Figure 3C. This pattern of abrupt changes in breakout character has been discussed by Paillet and Kim (1987) and Paillet (1988).

Wellbore enlargements (presumably breakouts) were located by inspection of borehole cross-sectional images averaged across 5 -cm-thick intervals throughout the entire length $(355 \mathrm{~m})$ of the BHTV log. Five scans (one scan line per centimeter) of traveltime data were superimposed in polar cross section to visually identify these features. Enlargements were liberally and consistently interpreted as the appearance of any obvious gap in the traveltime record. The results of this analysis are displayed in Figure 4, where 2720 such gaps are plotted as a function of azimuth and depth. Because the principal stresses are orthogonal, azimuths are presented over only a $180^{\circ}$ range. The data were corrected for tool position in the wellbore and for magnetic declination before plotting; they are also depicted in the histogram of Figure 5A. This distribution has a mean azimuth orientation with respect to magnetic north of $\mathrm{N} 114.4^{\circ} \mathrm{E}$, with a standard deviation of $\pm 17.7^{\circ}$. The mean value of the azimuth provides an estimate of the direction of least horizontal principal stress and agrees closely with that of Newmark et al. (1984), whose analysis of the BHTV log obtained from the upper kilometer of Hole 504B during DSDP Leg 83 yielded a mean azimuth of $\mathrm{N} 112^{\circ} \mathrm{E} \pm 16^{\circ}$. In the discussions to follow, it is argued that, because the breakout histogram is composed of a bimodal population, the orientation of $S_{h}$ needs to be based upon the primary mode, as opposed to the mean, of the statistical distribution. This interpretation will result in a slight correction to this initial estimate of stress direction.

Comparison of the results from the two complementary BHTV logs (Legs 83 and 111) indicates that the orientation of principal stresses remains relatively constant with depth through nearly $1300 \mathrm{~m}$ of the upper oceanic crust. However, the large scatter in the data (Fig. 4) and its non-normal distribution (Fig. 5A) poses some questions regarding the uniformity of principal stress orientation with depth and the actual initiation mechanism for rock failure. For example, the two paraelliptical cross sections shown in Figures $6 \mathrm{~A}$ and $6 \mathrm{~B}$ have major axes whose azimuths diverge substantially from each other. The occurrence of these opposing orientations in the BHTV record is frequent enough to account for the apparent bimodal distribution of the histogram in Figure 5A, where the primary and secondary modes are shown to be exactly $90^{\circ}$ apart.

In order to determine whether this presumed bimodality is statistically significant and truly represents the combination of two distinct populations or is simply a projection of substantial data scatter extending from a single, predominant mode, the technique of maximizing the likelihood function is applied to the data set shown in Figure 5 (Jones and James, 1969). In this statistical exercise, a density function is computed such that the probability of the data set originating from this function is maximized. This optimum distribution may be composed of one or two separate distributions. In order to allow for skewness and

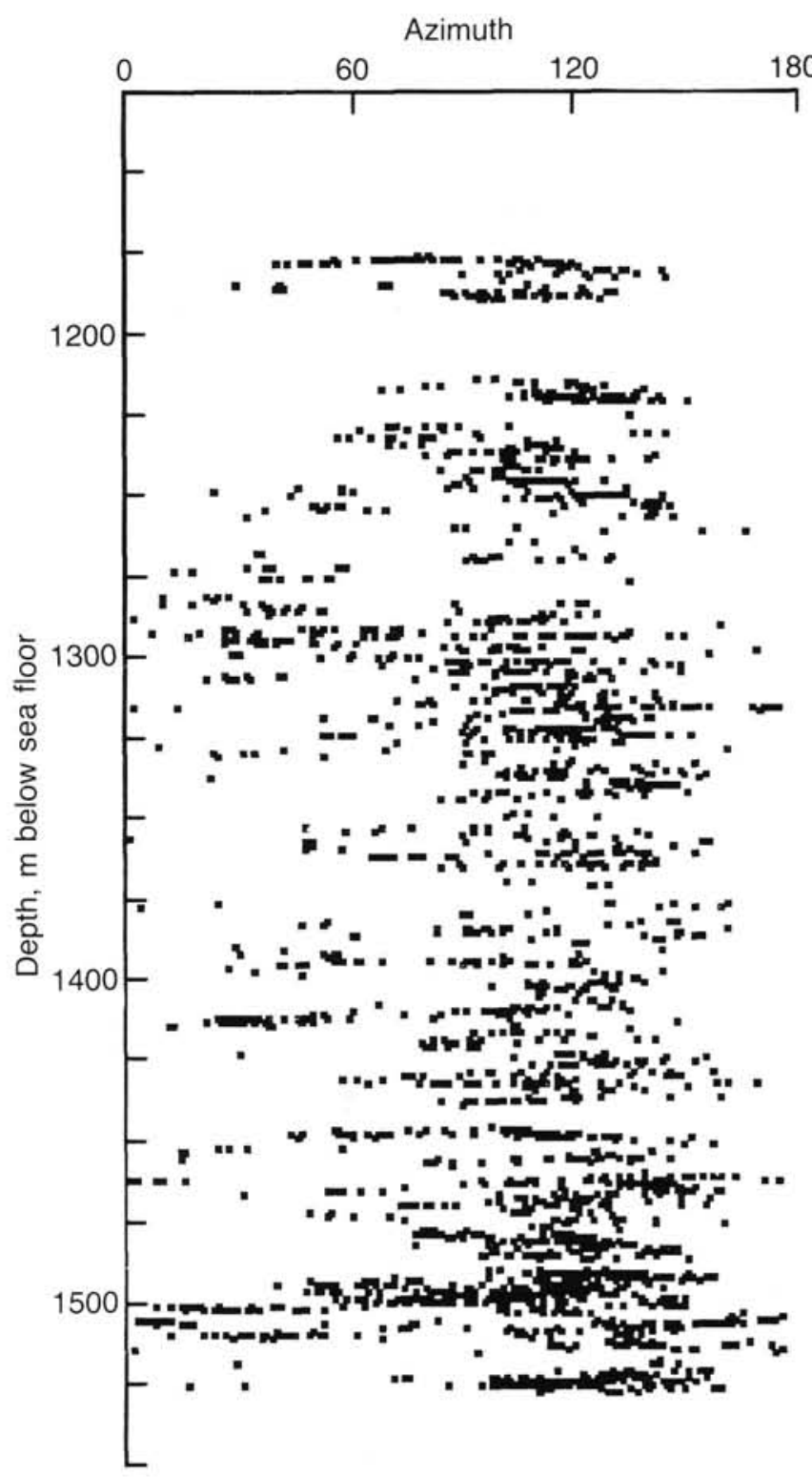

Figure 4. Distribution of breakout azimuths vs. depth.

make the analysis more flexible, beta distributions are used and the density function is defined as

$$
\begin{gathered}
f(x)=\left\{[1-\alpha] / B\left(\beta 1, \delta_{1}\right)\right\}(1 / \pi)(x / \pi)^{\beta_{1}}-1(1-x / \pi)^{\delta_{1}}-1 \\
+\left\{\alpha / B\left(\beta_{2}, \delta_{2}\right)\right\}(1 / \pi)(x / \pi)^{\beta_{2}}-1(1-x / \pi)^{\delta_{2}-1} \\
B(\beta, \delta)=\Gamma(\beta) \Gamma(\delta) / \Gamma(\beta+\delta) \\
\gamma=([\beta-1] \pi) /(\beta+\delta-2)
\end{gathered}
$$

where $f(x)$ is the density function associated with breakout frequency, $x$ is the azimuth (in radians), $\alpha$ is the proportion of all data points associated with the secondary population, $\alpha$ is the mode of each respective population (in radians), $B$ is the beta function, and $\Gamma$ is the gamma function. The parameters $\beta$ and $\delta$ are used to compute $B, \Gamma$, and $\gamma$.

The results of this test provide a unique numerical approximation to the breakout-vs.-azimuth distribution; this solution is presented in Figure 5B as a curved line. Values of the maximum 


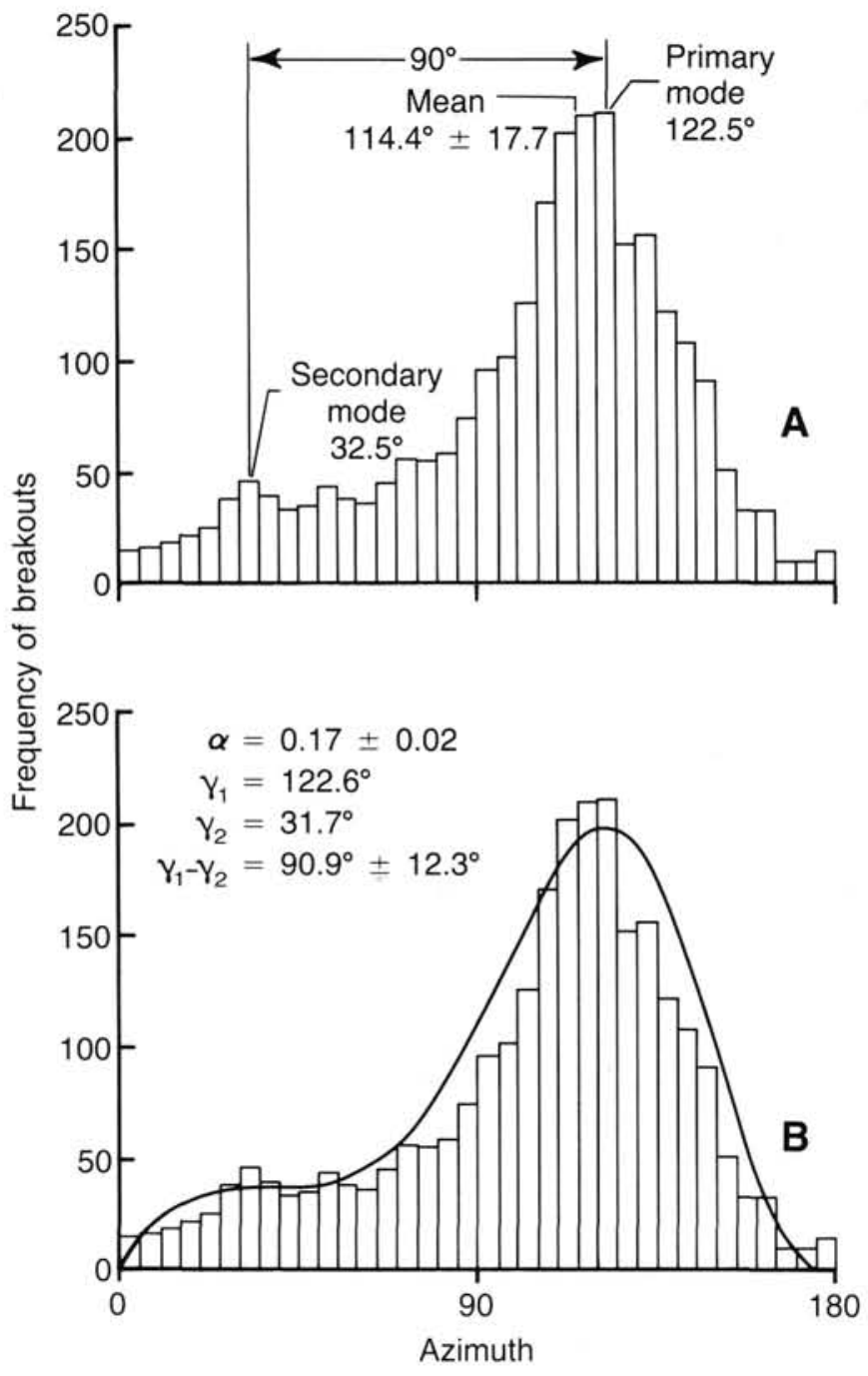

Figure 5. A. Histogram of breakout frequency vs. azimuth. Azimuths of mean and modes are identified. B. Approximation (curved line) of histogram developed from statistical density function. Terms are defined in text.

likelihood parameters (Hasselblad, 1966) that define this curve are as follows:

$$
\begin{aligned}
\alpha & =0.17 \pm 0.02 \\
\gamma_{2} & =31.7^{\circ} \\
\gamma_{1} & =122.6^{\circ} \\
\gamma_{1}-\gamma_{2} & =90.9^{\circ} \pm 12.3^{\circ} .
\end{aligned}
$$

Because $\alpha$ is not equal to zero, bimodality is established; that is, bimodality of the data set is statistically significant. Also, the values of the two modes estimated by this statistical technique are in excellent agreement with those identified directly from the histogram (Fig. 5A). The somewhat serendipitous observation that the two prominent modes associated with breakout frequency are approximately $90^{\circ}$ apart suggests that a significant number of wellbore enlargements occur in the direction of maximum principal stress. This type of bimodal, orthogonal pattern has been observed in several other wells (Blümling et al., 1983; Plumb and Hickman, 1985; Dart, 1987); a clear example of orthogonal enlargements in evidence at this site is illustrated in Figure 6C.

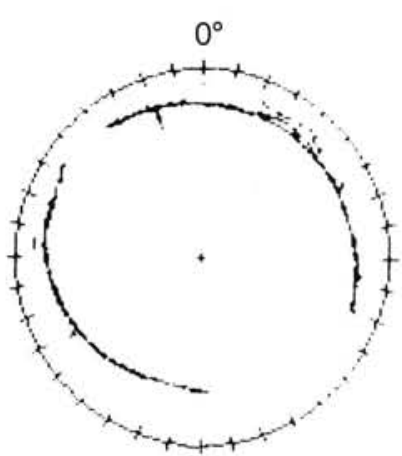

Depth, $m$

below sea

floor

1220.0

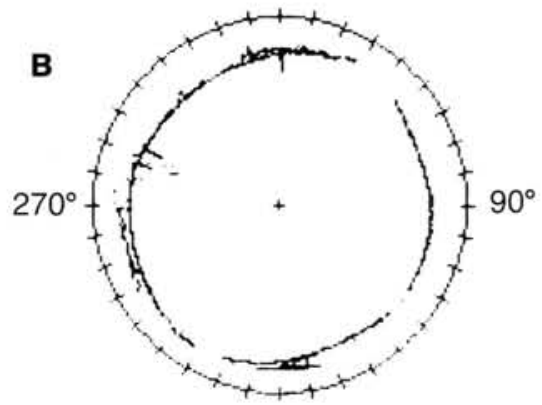

1293.3

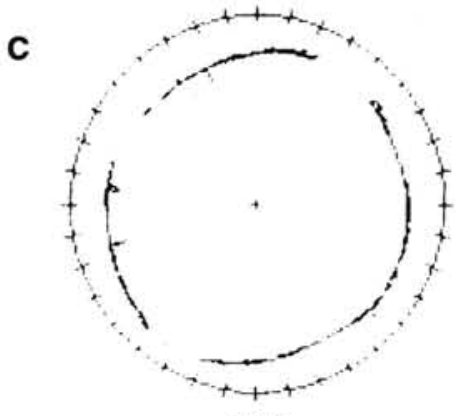

1293.5

Figure 6. Polar cross sections comparing ellipses for which the major axes are approximately orthogonal. See text for discussion of $\mathbf{A}, \mathbf{B}$, and C.

\section{Consequences of Slug Testing}

The term "breakout" as used in the previous discussion as well as in Figures 4 and 5 is a misnomer; it should refer specifically only to spalling that results from localized shear failure associated with a deviatoric state of stress about the wellbore. Other types of rock failure not strictly classified as breakouts probably account for many of the wellbore enlargements identified from the polar cross-sectional images, with hydraulic fracturing being the most likely. Hydrostatic pressures exert tensional stresses in the surrounding rock (Howard and Fast, 1970; Hickman and Zoback, 1983); this process could account for extensional rock failure in the $S_{H}$ direction and provide some explanation for the bimodal, orthogonal distribution presented in Figure 5. Unfortunately, no intentional hydraulic fracturing experiments have been conducted in Hole 504B and, consequently, no values of $S_{h}$ have been derived. Moreover, increases in borehole fluid pressure due to a heavy drilling mud or to the effects of unusual fluid circulation do not apply to Leg 111 drilling operations and, thus, cannot account for any significant generation of tensional stresses. 
It is also unlikely that slug tests conducted during DSDP Legs 83 and 92 (Anderson et al., 1985) and again during the early stages of Leg 111 (Becker, Sakai, et al., 1988), could have induced hydraulic fractures. The maximum pressure surge produced by any of these tests was only about $3.0 \mathrm{MPa}$, and none of the attendant pressure-time curves revealed the characteristic inflections attributed to the hydraulic fracturing process (Hickman and Zoback, 1983). Even if these moderate pressure increases had opened pre-existing fractures and caused extensional failure to propagate into the formation, slug testing was performed only across the upper part of the borehole before the deployment of the BHTV and, therefore, cannot account for the occurrence of wellbore enlargements along the $S_{H}$ azimuth at depths below 1350 mbsf. The final Leg 111 slug test reported by Becker, Sakai, et al. (1988) exposed the lower part of the formation to elevated pressures, but this experiment was performed after the BHTV log had been completed. Thus, slug testing does not seem to adequately explain the generation of extensional fractures and the associated orthogonal distribution of wellbore enlargements. However, it is possible that the dynamic drilling process could have concentrated stresses at the drill bit (Peltier and Atkinson, 1987) and caused localized chipping of the surrounding rock, perhaps preferentially opening fractures oriented in the $S_{H}$ direction.

\section{Consequences of an Elliptical Borehole}

In order to further consider this issue of rock failure, the stress distribution around a borehole is examined as its crosssectional shape changes from circular to elliptical. This type of deformation may be attributed to differential strain in the rock (Blanton and Teufel, 1985) or to asymmetric drill-pipe wear. As in the previous case of the circular hole with hydrostatic pressure conditions, $\sigma_{r}$ and $\tau_{r \theta}$ reduce to zero at the borehole wall, and the distribution of circumferential stress around an elliptical borehole is determined to be (Timoshenko and Goodier, 1970)

$$
\begin{aligned}
\sigma_{\theta}= & \left(\bar{S}_{H}\left[\sinh 2 \psi+e^{2 \psi} \cos 2 \theta-1\right]\right. \\
& \left.+\bar{S}_{h}\left[\sinh 2 \psi-e^{2 \psi} \cos 2 \theta+1\right]\right) /(\cosh 2 \psi-\cos 2 \theta),
\end{aligned}
$$

where the dimension $\psi$ remains constant around the borehole wall. The major and minor elliptical axes are represented by the terms $a$ and $b$, respectively (Fig. 7A). These parameters are related by the expression

$$
\operatorname{coth} \psi=a / b .
$$

As in the circular borehole, $\sigma_{\theta}$ is a maximum at $\theta=0^{\circ}$ and a minimum at $\theta=90^{\circ}$; therefore,

$$
\begin{aligned}
& \text { At } \theta=0^{\circ}, \sigma_{\theta}=\bar{S}_{H}(1+2 a / b)-\bar{S}_{h} \\
& \text { At } \theta=90^{\circ}, \sigma_{\theta}=\bar{S}_{h}(1+2 b / a)-\bar{S}_{H} .
\end{aligned}
$$

When the borehole is circular $(a=b)$; equations (11) and (12) reduce to equations (4) and (5). The distribution of circumferential stress around a borehole is displayed in Figure 7B for several values of eccentricity $(n)$, where $n$ is defined as

$$
n=2(a-b) /(a+b) .
$$

For small values of $n(<0.10), \mathrm{n} \approx(a / b)-1.0$.

The stress distributions depicted in Figure $7 \mathrm{~B}$ were computed with the ratio of effective principal stresses $\left(\bar{S}_{H} / \bar{S}_{h}\right)$ assumed to be 3.0. This magnitude yields large stress concentrations coincident with the $S_{h}$ direction that are not unrealistically high (Zo-
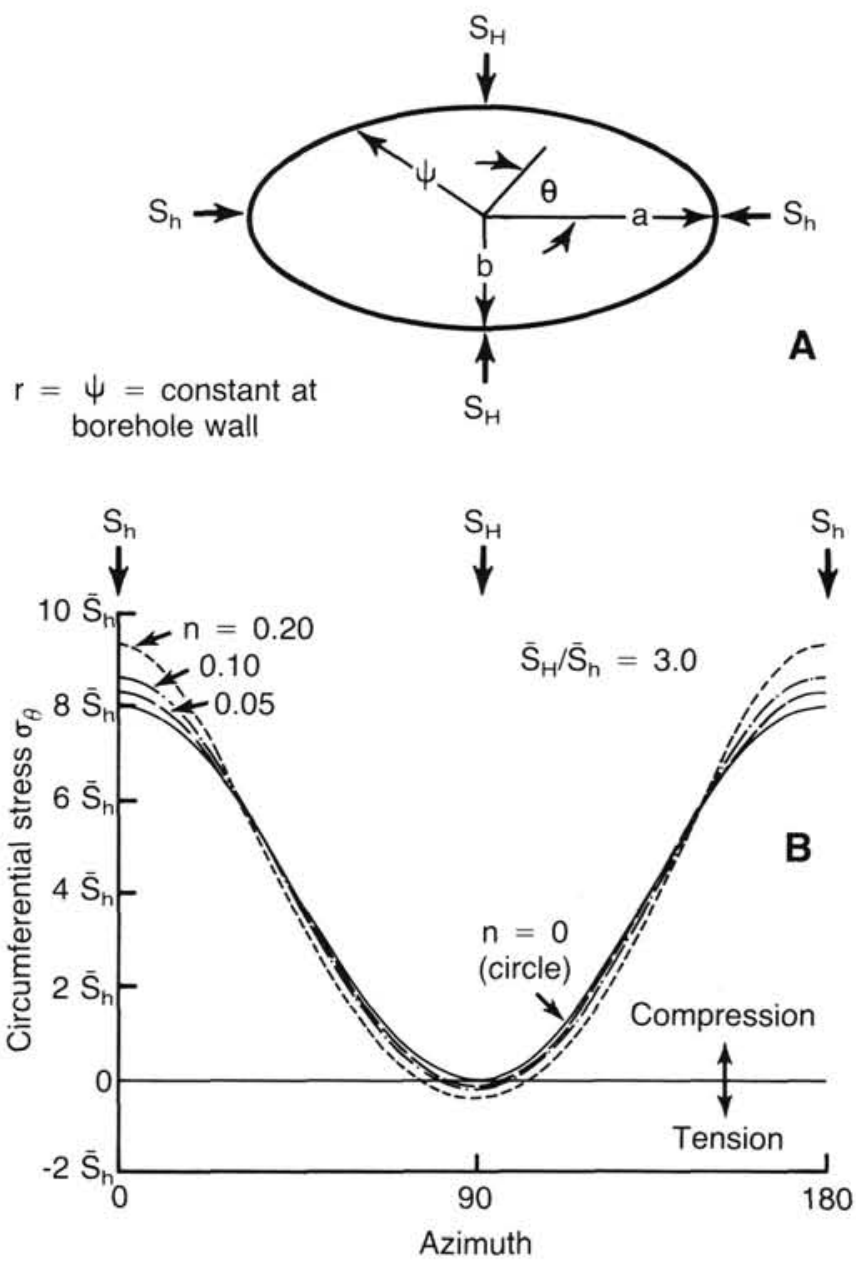

Figure 7. Schematic diagrams of (A) elliptical borehole cross section with (B) corresponding distribution of circumferential stress for variable eccentricity, $n$, and $\bar{S}_{H} / \bar{S}_{h}=3.0$. Terms are defined in the text.

back et al., 1985). Examination of the curves in Figure 7B shows that an increase in eccentricity produces an increase in circumferential stress at $\theta=0^{\circ}$, the orientation of both the major axis and the minimum principal stress. In addition, this change in cross-sectional shape reduces the circumferential stress at the azimuth of the maximum principal stress $\left(\theta=90^{\circ}\right)$. In this case, where $\bar{S}_{H} / \bar{S}_{h}$ equals 3.0 , the decrease actually places the formation in tension, thereby demonstrating that, under certain sets of conditions, hydraulic fracturing can be induced by the development of ellipticity in the borehole. A similar distribution of tensional stresses can also be produced if $\bar{S}_{H} / \bar{S}_{h}$ exceeds 3.0 in a circular hole. Although this situation may be unlikely, Brace and Kohlstedt (1980) showed that the ratio $\bar{S}_{H} / \bar{S}_{h}$ may climb to as high as 5.0 for rocks with friction coefficients that approach an upper limit of 1.0 (Zoback and Healy, 1984). Thus, ellipticity is not essential for the development of tensile stresses.

If failure occurs along pre-existing fractures, the surrounding rock can be assumed to have no inherent tensile strength (Bredehoeft et al., 1976). Based on the Mohr-Coulomb criteria for failure, this introduction of tensional stress should produce mechanical failure along an azimuth that corresponds to the direction of maximum horizontal principal stress. The combination of high principal stress ratio and small eccentricity could account for the bimodal, orthogonal distribution of fractures shown in Figure 5 and for the appearance of ellipses with op- 
posing orientations shown in Figure 6 . The analytical curves in Figure 8 demonstrate that as the ratio of $\bar{S}_{H}$ to $\bar{S}_{h}$ decreases, the degree of ellipticity required to produce tensional failure increases rapidly. In theory, any slight amount of eccentricity will generate tensional stresses at an azimuth coincident with $S_{H}$ when $\bar{S}_{H} / \bar{S}_{h}$ equals 3.0 . This eccentricity threshold increases to 0.30 when $S_{H} / \bar{S}_{h}$ is 2.5 and approaches 0.60 when $\bar{S}_{H} / \bar{S}_{h}$ is 2.0 .

Stock et al. (1985) compared the physical characteristics of breakouts and hydraulic fractures and identified some consistent differences. Whereas breakouts usually are broad bands that occur sporadically in the borehole wall, hydraulic fractures typically are narrow and continuous. These latter features could not be readily identified in the BHTV photographic record. As illustrated in Figure 6, gaps in the polar cross section of the wellbore were as broad, deep, and periodic along the $S_{H}$ azimuth (presumably hydrofractures) as they were along the $S_{h}$ azimuth (presumably breakouts). This implies that extensional fracturing around the borehole and into the formation was more pronounced than that commonly associated with hydraulic fracturing tests. An explanation for this general observation is difficult, although it may be an indication of a low $S_{h}$ magnitude. This condition would enable cracks to propagate deeper into the formation, producing more extensive zones of rock failure.

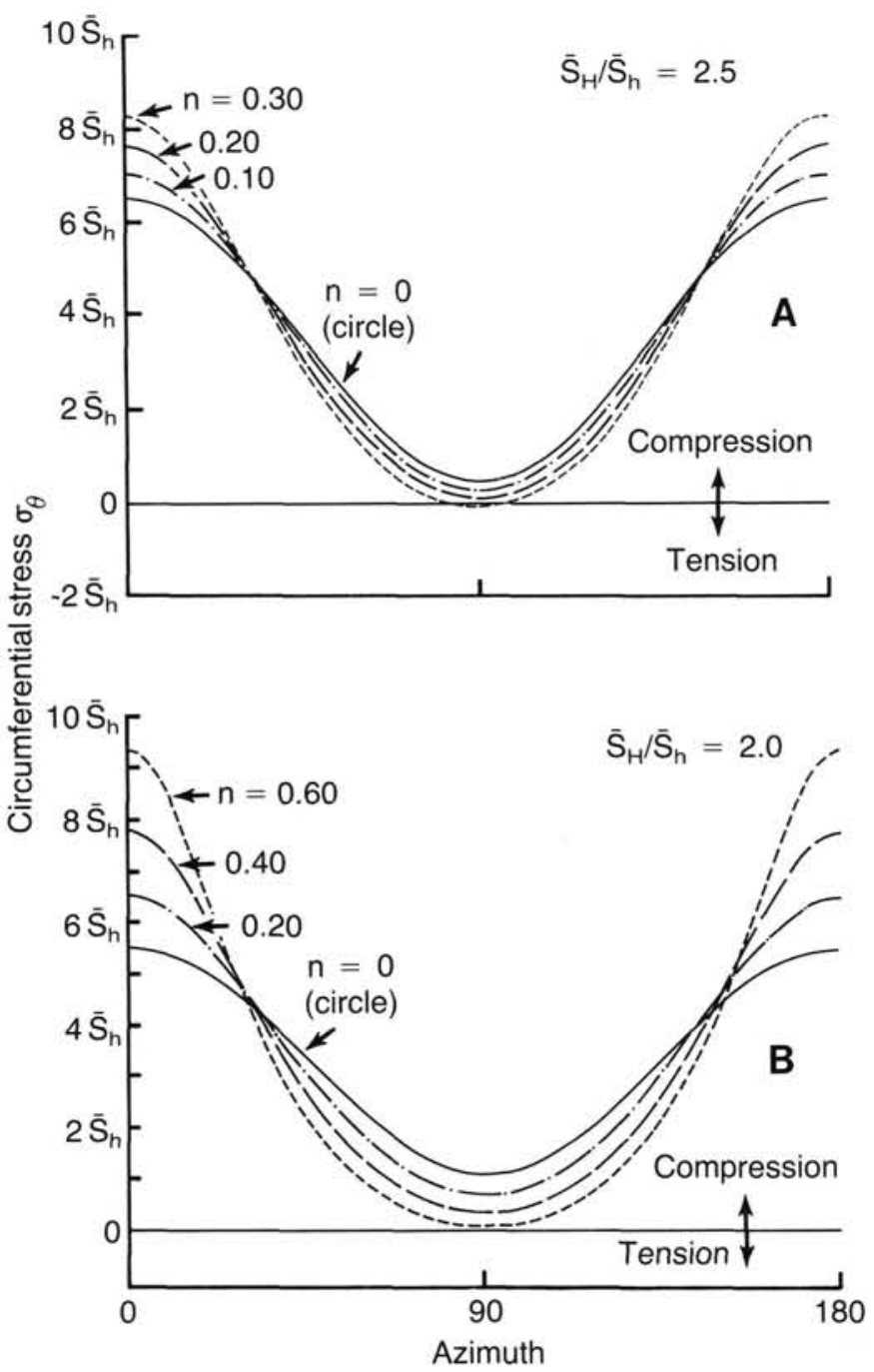

Figure 8. Distribution of circumferential stress around a borehole with variable eccentricity, $n$. A. $\bar{S}_{H} / \bar{S}_{h}=2.5$. B. $\bar{S}_{H} / \bar{S}_{h}=2.0$.
Dart and Zoback (1989) recognized similar bimodal, orthogonal distributions of borehole elongations in petroleum exploration wells and categorized sets of physical conditions that might promote the development of these remarkable patterns, including (1) preferentially oriented washouts formed by circulation of drilling fluid, (2) elliptical enlargements in poorly consolidated sediments, (3) eccentric tool wear resulting from hole deviation, and (4) hydraulic fracturing caused by an increase in drillingfluid weight. The first two conditions are not commonly applied directly to crystalline rock formations; the third also is not likely because Hole 504B does not deviate more than a few degrees from vertical. However, the abrasive effects of repeated pipe trips may have produced occasional evidence of wellbore asymmetry and increased the possibility of hydraulic fracturing. The fourth condition was addressed by a previous discussion that concluded that increases in borehole fluid pressure produced by drilling mud or slug testing were not considered substantial enough to induce extensional fracturing. However, the effects of the dynamic drilling process, though not well understood, should not be discounted. Localized chipping adjacent to the drill bit may account for the generally intermittent, broad, and discontinuous character of the tensile fractures.

After consideration of these various explanations for the development of an orthogonal distribution of borehole enlargements, it seems plausible that the extensional fractures detected at Hole 504B could have been caused by slight eccentricities in the wellbore shape if the ratio of horizontal principal stresses was high. These enlargements could also have been produced along pre-existing cracks in a circular borehole if the stress ratio exceeded a magnitude of 3.0. A low stress ratio is more likely to promote spalling of a random and discontinuous nature, but the prominent primary mode depicted in Figure 5 suggests that this is not the case, thereby providing further qualitative confirmation that $\bar{S}_{H} / \bar{S}_{h}$ is fairly high at this site. In addition, the broad extent of the presumed hydraulic fractures implies that the minimum horizontal principal stress is low. Breakouts usually are the only visible feature associated with borehole deformation and stress concentration. This situation promotes the development of the familiar breakout frequency distribution containing a single, predominant mode. This type of distribution commonly is normal, and its statistical mean routinely has been computed to estimate the $S_{h}$ orientation. However, the appearance of a secondary mode exerts a bias on the mean that causes it to depart slightly from the primary mode. Thus, the mean of a bimodal population no longer accurately represents the orthogonal orientations of $S_{H}$ and $S_{h}$; however, the azimuths of the two modes do. Examination of Figure 5A shows that this discrepancy can be corrected by rotating the $S_{h}$ azimuth $\mathrm{N} 8^{\circ} \mathrm{E}$. The $S_{h}$ direction now is estimated to be $\mathrm{N} 122.5^{\circ} \mathrm{E}$, a direction that still correlates well with the $\mathrm{N} 112^{\circ} \mathrm{E} \pm 16^{\circ}$ estimate reported by Newmark et al. (1984).

\section{Correlation with Tectonic Forces}

Compressive stresses in the oceanic lithosphere can be generated by elevated topography at ridge axes and by the subsequent thickening of the plate with age. Other stresses can be related to forces such as drag and slab pull. Consequently, the orientation of horizontal principal stresses at a particular site is a measure of the intraplate stress field that, in turn, reflects the distribution of the dominant driving forces at plate boundaries. It seems reasonable to speculate that the region surrounding Hole $504 \mathrm{~B}$ is undergoing north-northeast-south-southwest compression as a direct result of the dominant ridge push being generated at the Costa Rica Rift, a compressive force perpendicular to the ridge axis (e.g., Dahlen, 1981). In addition, slab pull along the subduction zone to the east could produce a small, 
possibly tensional, stress component almost perpendicular to the direction of ridge push (see Fig. 9).

This first-order interpretation of stress orientation coincides well with that determined from the foregoing BHTV breakout analysis and even accounts for the small magnitude of $\bar{S}_{h}$. However, the northeastern corner of the Nazca plate is a region for which the stress field associated with tectonic features is very complex (Richardson and Cox, 1984). The Nazca plate perimeter consists of a subduction zone adjacent to South America, with spreading centers and transform faults along the other boundaries. It also contains hot spots, intraplate ridges, and possible microplates (Lonsdale, 1987). Moreover, in young oceanic lithosphere $(<35 \mathrm{~m} . \mathrm{y}$.), local stress orientations are primarily the manifestation of the thermoelastic stresses attendant with the rapid early cooling of the plate (Bratt et al., 1985). Thus, the oceanic crust at this site seems to be too young and tectonically complex to justify a correlation between the principal stress orientation derived from breakouts at Hole 504B and the major driving forces at the nearby plate boundaries.

It is possible, however, to correlate seismic activity to the state of stress in the source region. Bergman (1986) presented a detailed overview of oceanic intraplate seismicity, with estimates of stress orientations inferred from earthquake focal mechanisms. The directions of principal stresses derived from several intraplate earthquakes originating near Hole 504B, as well as the direction of $S_{H}$ determined from analysis of the BHTV record, are illustrated in Figure 9. There is remarkably good agreement in the data, even at locations to the north of the Cocos-Nazca spreading system.

All of these earthquakes have fault-plane solutions indicating strike-slip failure (Bergman and Solomon, 1984). This condition implies a relative order in the principal stress magnitudes,

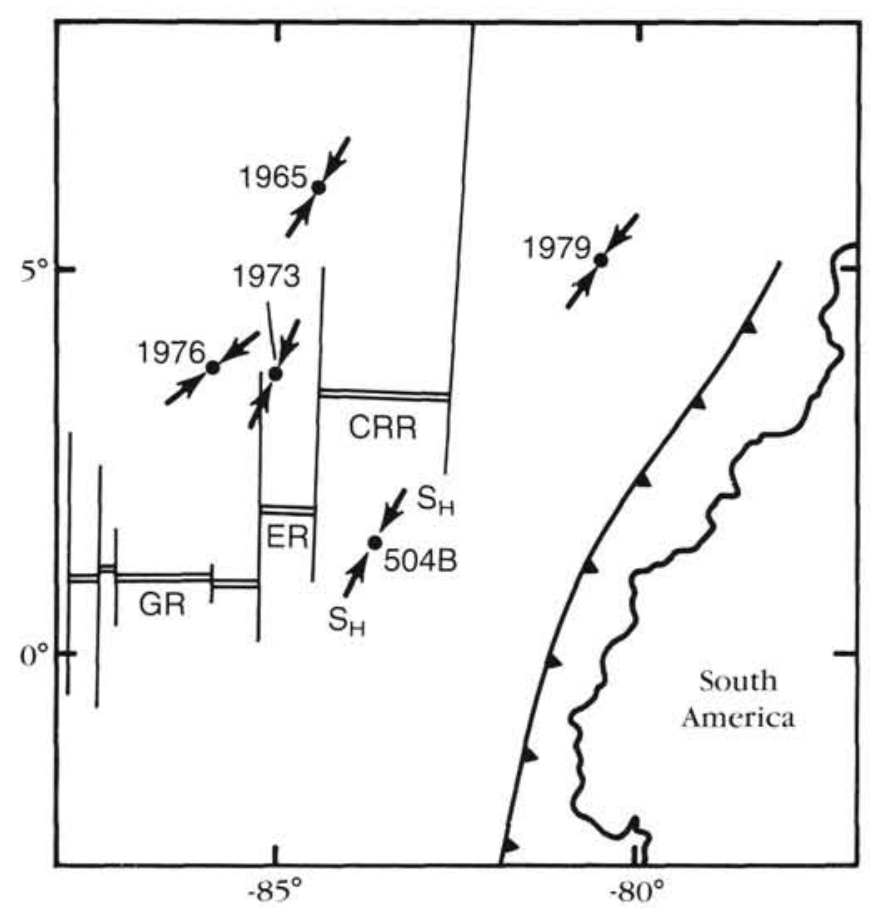

Figure 9. Orientations of maximum horizontal principal stress inferred from focal mechanisms of intraplate earthquakes (with date of occurrence) and from breakout analysis of the BHTV log for Hole 504B. Double lines locate the Cocos-Nazca spreading system, and the spiked line indicates the Peru-Chile Trench. CRR = Costa Rica Rift; ER = Ecuador Rift; $G R=$ Galapagos Rift. Adapted from Newmark et al. (1984) and Bergman (1986).
$\bar{S}_{H}>\bar{S}_{v}>\bar{S}_{h}$ (e.g., Golombek, 1985), as well as the strong likelihood that the stress ratio, $\bar{S}_{H} / \bar{S}_{h}$, is large. Blümling et al. (1983) performed a similar breakout analysis in crystalline rock and also reported a bimodal, orthogonal distribution of borehole enlargements in a region associated with strike-slip focal mechanisms. Perhaps the clear detection of orthogonal enlargements in a wellbore that has not specifically been exposed to hydraulic fracturing tests indicates that the particular combination of stress ratio, magnitude, and orientation is such that strikeslip faulting is the most probable means of earthquake generation.

\section{LITHOSTRATIGRAPHY}

Ophiolite complexes are generally thought to be exposures of ancient ocean lithosphere. When considering lithostratigraphy, the ophiolite analogy and attendant models have been applied to the contemporary oceanic crust (Salisbury and Christensen, 1978; Casey et al., 1981). Anderson et al. (1982) presented a thorough interpretation of the structure of the ocean basement at Hole 504B based on the numerous geophysical logs and core analyses generated from DSDP Leg 83 . This generalized lithostratigraphy, including ODP Leg 111, is shown in Figure 10 and corresponds to the upper components of a conventional layered ophiolite suite (Coleman, 1977).

Overall, the recent BHTV log contributes little to this structural interpretation, with the exception of several instances where images of spherical features were detected. The deepest of these was observed at a depth of 1475 mbsf and is shown in Figure 11. These stacked patterns appear to be pillows having a diameter of approximately $0.2 \mathrm{~m}$. Other possible scenarios for the generation of this type of geometric shape, such as the intersection of undulating fractures or dike margins with the borehole wall, have been considered, but none seem particularly plausible.

Assuming that these features are indeed pillow basalts, then their location needs to be evaluated within the lithostratigraphic context of Figure 11. These pillows are observed less than $100 \mathrm{~m}$ from the bottom of the hoie and $420 \mathrm{~m}$ below the lower bound of the transition zone, deep within the sheeted dikes. As dikes progressively increase in frequency with depth, the transition from pillow lavas and minor flows to variably metamorphosed diabase dikes can be quite gradual and gradational (Kidd, 1977). Karson et al. (1984) used a statistical approach to assign lithologic units by identifying points at which greater than $90 \%$ of a single lithology is present. The transition zone in Hole 504B was constrained to its present lower bound during DSDP Leg 83 by shipboard petrographers to where the last evidence of pillows

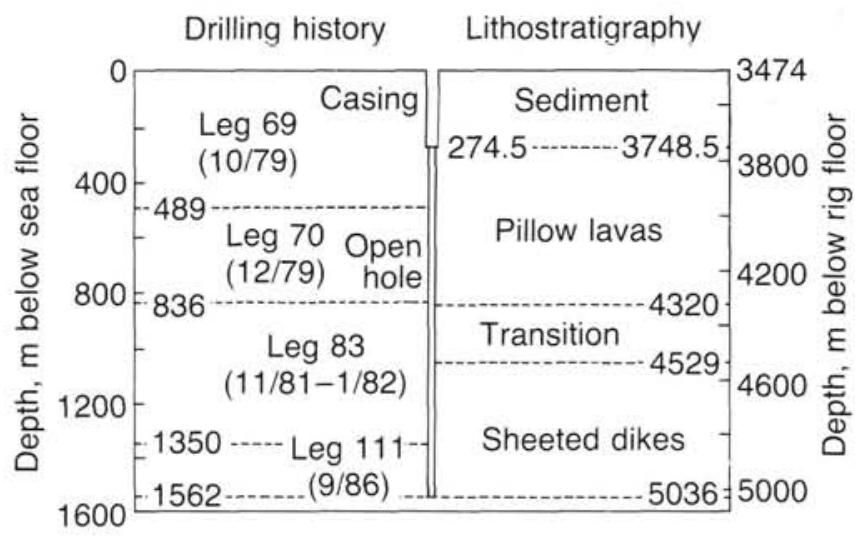

Figure 10. Schematic diagram of drilling history and generalized lithostratigraphy at Hole 504B (adapted from Anderson, Honnorez, et al., 1985). 


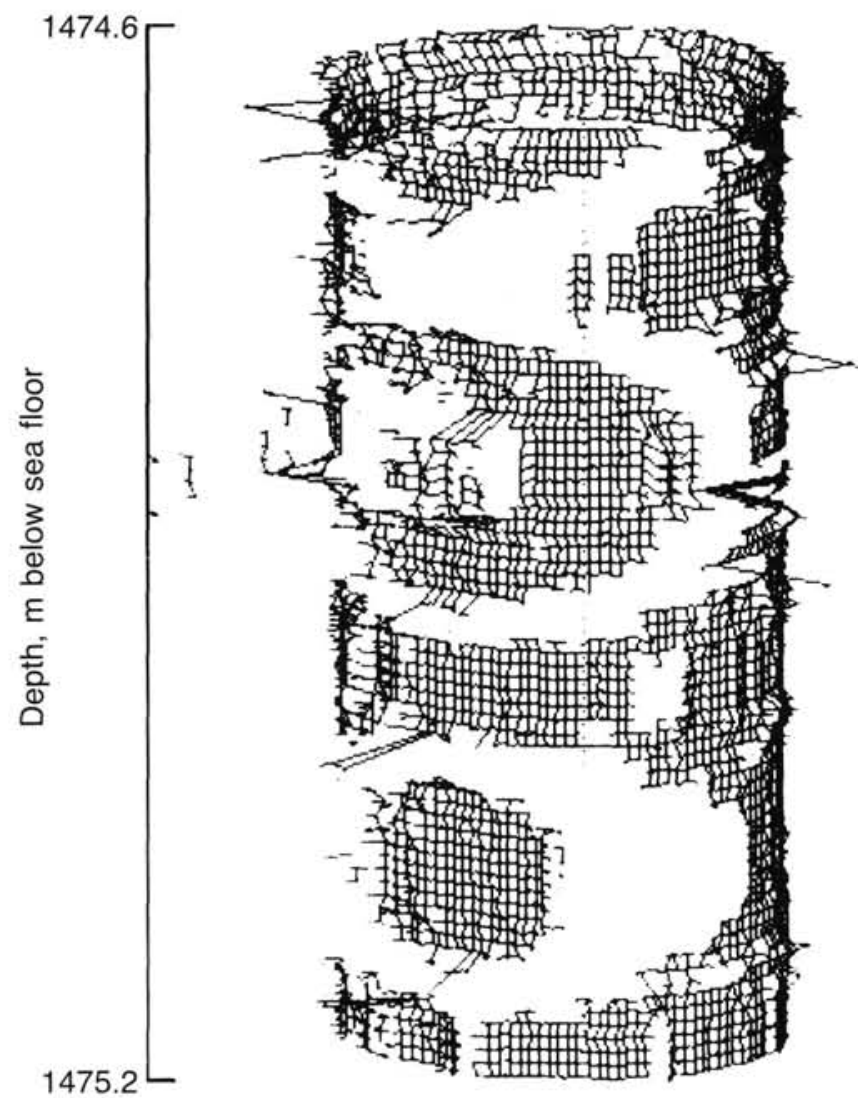

Figure 11. Three-dimensional image of pillow basalts from 1474.6 to 1475.2 mbsf processed from BHTV record.

was recovered from coring operations. This detection of pillow lavas at a depth of 1475 mbsf indicates that the structure of this transitional unit may be a complex interlayering of lithologies that extends over a thicker vertical interval than previously thought.

\section{CONCLUSIONS}

The borehole televiewer log obtained in the lower part of Hole 504B during ODP Leg 111 has proven to be very useful in characterizing the in-situ stress field at this site. An examination of breakout frequency vs. azimuth for a 355 -m vertical section of the borehole defined the orientation of horizontal principal stresses according to the well-substantiated hypothesis that breakouts occur coincident with the direction of minimum principal stress, where differences in compressive forces are at their greatest. This stress orientation agrees closely with the results of a previous BHTV study of breakouts in the upper section of this same well and also with stress orientation estimates inferred from regional intraplate earthquakes.

Further inspection of the breakout histogram revealed the unmistakable development of a second mode separated from its primary counterpart by approximately $90^{\circ}$. The bimodal, orthogonal character of this frequency distribution was shown to be statistically significant and indicated that a considerable number of wellbore enlargements were not breakouts at all, but possibly hydraulic fractures induced by tensional stresses along the $S_{H}$ azimuth. This was confirmed by inspection of individual cross-sectional images of the wellbore processed from the BHTV record. After considering several schemes for the possible generation of these tensional stresses in a borehole that had not specifically undergone hydraulic fracturing experiments, it was hypothesized that a high ratio of horizontal principal stresses oc- curring around a borehole having a slight degree of ellipticity, or an even higher stress ratio around a cylindrical borehole, provided the most reasonable explanation for observed conditions. It was further postulated that the deep and prominent appearance of the extensional fractures may be due to a low magnitude of $\bar{S}_{h}$, which could enable pre-existing fractures to propagate into the formation. The abrupt, periodic occurrence of breakouts throughout the well and the dominant strike-slip focal mechanisms associated with regional earthquakes both implied a high ratio of $\bar{S}_{H}$ to $\bar{S}_{h}$ and helped corroborate these conclusions. However, no quantitative measurements of principal stresses have been conducted at this site, and speculation concerning their relative magnitudes must be limited to qualitative attempts.

The BHTV record can help characterize the lithostratigraphy at Hole 504B, particularly when combined with other geophysical log measurements that penetrate deep into the formation and yield information regarding physical properties and geochemical composition. The visual detection of pillow basalts deep in the sheeted dike unit and less than $100 \mathrm{~m}$ from the bottom of the hole is a cause for re-evaluation of the generalized lithostratigraphy initially developed during DSDP Leg 83 for this site. The transition from pillow lavas and minor flows to the variably metamorphosed dikes may extend over a substantially thicker interval of basement.

\section{ACKNOWLEDGMENTS}

We would like to thank S. Hickman and R. Dart for their thoughtful and deliberate reviews of this paper. Additional discussions with $\mathrm{E}$. Bergman, R. Denlinger, and F. Paillet were also helpful. B. Troutman's help with the statistical analyses is particularly appreciated.

\section{REFERENCES}

Anderson, R. N., Honnorez, J., Becker, K., et al., 1985. Init. Repts. DSDP, 83: Washington (U.S. Govt. Printing Office).

Anderson, R. N., Honnorez, J., Becker, K., Adamson, A. C., Alt, J. C., Emmermann, R., Kempton, P. D., Kinoshita, H., Laverne, C., Mottl, M. J., and Newmark, R. L., 1982. DSDP Hole 504B, the first reference section over $1 \mathrm{~km}$ through Layer 2 of the oceanic crust. Nature, 300:589-594.

Anderson, R. N., Zoback, M. D., Hickman, S. H., and Newmark, R. L., 1985. Permeability versus depth in the upper oceanic crust: in situ measurements in DSDP Hole 504B, eastern equatorial Pacific. J. Geophys. Res., 90:3659-3669.

Barton, C. A., Zoback, M. D., and Burns, K. L., 1988. In-situ stress orientation and magnitude at the Fenton geothermal site, New Mexico, determined from wellbore breakouts. Geophys. Res. Lett., 15: 467-470.

Becker, K., Sakai, H., et al., 1988. Proc. ODP, Init. Repts., 111: College Station, TX (Ocean Drilling Program).

Bell, J. S., and Gough, D. I., 1979. Northeast-southwest compressive stress in Alberta: evidence from oil wells. Earth Planet. Sci. Lett., $45: 475-482$.

Bergman, E. A., 1986. Intraplate earthquakes and the state of stress in oceanic lithosphere. Tectonophysics, 132:1-35.

Bergman, E. A., and Solomon, S. C., 1984. Source mechanisms of earthquakes near mid-ocean ridges from body waveform inversion: implications for the early evolution of oceanic lithosphere. J. Geophys. Res., 89:11,415-11,441.

Blanton, T. L., and Teufel, L. W., 1985. In-situ stress determination from wellbore elongation measurements. Proc., SPE/DOE Symp. Low Permeability Gas Reservoirs, 279-291.

Blümling, P., Fuchs, K., and Schneider, T., 1983. Orientation of the stress field from breakouts in a crystalline well in a seismic active area. Phys. Earth Planet. Inter, 33:250-254.

Brace, W. F., and Kohlstedt, D. L., 1980. Limits on lithospheric stress imposed by laboratory experiments. J. Geophys. Res., 85:6248-6252.

Bratt, S. R., Bergman, E. A., and Solomon, S. C., 1985. Thermoelastic stress: how important as a cause of earthquakes in young oceanic lithosphere? J. Geophys. Res., 90:10,249-10,260. 
Bredehoeft, J. D., Wolff, R. G., Keys, W. S., and Shuter, E., 1976. Hydraulic fracturing to determine the regional in-situ stress field, $\mathrm{Pi}$ ceance Basin, Colorado. Geol. Soc. Am. Bull., 87:250-258.

Cann, J. R., Langseth, M. G., Honnorez, J., Von Herzen, R. P., White, S. M., et al., 1983. Init. Repts. DSDP, 69: Washington (U.S. Govt. Printing Office).

Casey, J. F., Dewey, J. F., Fox, P. J., Karson, J. A., and Rosencrantz, E., 1981. Heterogeneous nature of the oceanic crust and upper mantle: a perspective from the Bay of Islands ophiolite. In Emiliani, C. (Ed.), The Sea (vol. 7): New York (Wiley), 305-338.

Coleman, R. G., 1977. Ophiolites: Ancient Oceanic Lithosphere: New York (Springer-Verlag).

Dahlen, F. A., 1981. Isostasy and the ambient state of stress in the oceanic lithosphere. J. Geophys. Res., 86:7801-7807.

Dart, R. L., 1987. South-Central United States Well-Bore BreakoutData Catalog: U.S. Geol. Surv. Open-File Rep., 87-405.

Dart, R. L., and Zoback, M. L., 1989. Well-bore breakout-stress analysis within the continental United States. Log Analyst, 30(1):12-25.

Georgi, D. T., 1985. Geometrical aspects of borehole televiewer images. Trans. SPWLA 26th Annu. Logging Symp., Pap. 0:1-20.

Golombek, M. P., 1985. Fault type predictions from stress distributions on planetary surfaces: importance of fault initiation depth. J. Geophys. Res., 90:3065-3074.

Gough, D. I., and Bell, J. S., 1982. Stress orientations from borehole wall fractures with examples from Colorado, East Texas, and northern Canada. Can. J. Earth Sci., 19:1358-1370.

Hasselblad, V., 1966. Estimation of parameters for a mixture of normal distributions. Technometrics, 8:431-444.

Hickman, S. H., Healy, J. H., and Zoback, M. D., 1985. In situ stress, natural fracture distribution, and borehole elongation in the Auburn geothermal well, Auburn, New York. J. Geophys. Res., 90:54975512.

Hickman, S. H., and Zoback, M. D., 1983. The interpretation of hydraulic fracturing pressure-time data for in situ stress determination. Proc. Workshop Hydraulic Fracturing Stress Measurements: Washington (U.S. Natl. Comm. on Rock Mechanics), 51-60.

Howard, G. C., and Fast, C. R., 1970. Hydraulic Fracturing: Monogr. Ser., Soc. Petrol. Eng. AIME, 2.

Jaeger, J. C., and Cook, N.G.W., 1976. Fundamentals of Rock Mechanics: New York (Wiley).

Jones, T. A., and James, W. R., 1969. Analysis of bimodal orientation data. Math. Geol., 1:129-135.

Karson, J. A., Collins, J. A., and Casey, J. F., 1984. Geologic and seismic velocity structure of the crust/mantle transition in the Bay of Islands ophiolite complex. J. Geophys. Res., 89:6126-6138.

Kidd, R.G.W., 1977. A model for the process of formation of the upper oceanic crust. Geophys. J. R. Astron. Soc., 50:149-183.

Leinen, M., Rea, D. K., Becker, K., et al., 1986. Init. Repts. DSDP, 92: Washington (U.S. Govt. Printing Office).

Lonsdale, P., 1987. The boundaries of the Galapagos microplate. EOS, Trans. Amer. Geophys. Union, 68:1476. (Abstract)

Lysne, P., 1986. Determination of borehole shape by inversion of televiewer data. Log Analyst, 27(3):64-71.
Newmark, R. L., Anderson, R. N., Moos, D., and Zoback, M. D., 1985. Sonic and ultrasonic logging of Hole 504B and its implications for the structure, porosity, and stress regime of the upper $1 \mathrm{~km}$ of the oceanic crust. In Anderson, R. N., Honnorez, J., Becker, K., et al., Init. Repts. DSDP, 83: Washington (U.S. Govt. Printing Office), 479-510.

Newmark, R. L., Zoback, M. D., and Anderson, R. N., 1984. Orientation of in situ stresses in the oceanic crust. Nature, 311:424-428.

Paillet, F. L., 1988. Fracture Characterization and Fracture Permeability Estimation at the Underground Research Laboratory in Southeastern Manitoba, Canada: Water-Resour. Invest., U.S. Geol. Surv., 88-4009.

Paillet, F. L., and Kim, K., 1987. Character and distribution of borehole breakouts and their relationship to in situ stresses in deep Columbia River basalts. J. Geophys. Res., 92:6223-6234.

Peltier, B., and Atkinson, C., 1987. Dynamic pore pressure ahead of the bit. SPE Drilling Engrg., 33(6):351-358.

Plumb, R. A., and Cox, J. W., 1987. Stress directions in eastern North America determined to $4.5 \mathrm{~km}$ from borehole elongation measurements. J. Geophys. Res., 92:4805-4816.

Plumb, R. A., and Hickman, S. H., 1985. Stress-induced borehole elongation: a comparison between the four-arm dipmeter and the borehole televiewer in the Auburn geothermal well. J. Geophys. Res., 90:5513-5521.

Richardson, R. M., and Cox, B. L., 1984. Evolution of oceanic lithosphere: a driving force study of the Nazca plate. J. Geophys. Res., $89: 10,043-10,052$.

Salisbury, M. H., and Christensen, N. I., 1978. The seismic velocity structure of a traverse through the Bay of Islands ophiolite complex, Newfoundland: an exposure of oceanic crust and upper mantle. $J$. Geophys. Res., 83:805-817.

Stock, J. M., Healy, J. H., Hickman, S. H., and Zoback, M. D., 1985. Hydraulic fracturing stress measurements at Yucca Mountain, Nevada, and relationship to the regional stress field. J. Geophys. Res., 90:8691-8706.

Teufel, L. W., 1985. In-situ stress state in the Mounds test well as determined by the anelastic strain recovery method. Proc., SPE/DOE Symp. Low Permeability Gas Reservoirs, 467-474.

Timoshenko, S. P., and Goodier, J. N., 1970. Theory of Elasticity: New York (McGraw-Hill).

Zemanek, J., Caldwell, R. L., Glenn, E. E., Jr., Holcomb, S. V., Norton, L. J., and Straus, A.J.D., 1969. The borehole televiewer-a new logging concept for fracture location and other types of borehole inspection. J. Pet. Technol., 21:762-774.

Zoback, M. D., and Healy, J. H., 1984. Friction, faulting, and in situ stress. Ann. Geophys. Gauthier-Villars, 2:689-698.

Zoback, M. D., Moos, D., Mastin, L., and Anderson, R. N., 1985. Well bore breakouts and in situ stress. J. Geophys. Res., 90:55235530 .

Date of initial receipt: 15 April 1988

Date of acceptance: 23 February 1989

Ms 111B-137 